\title{
Means to Elevate Employment Competence in Sino- Foreign Cooperative Education
}

\author{
Runtong $\mathrm{Yu}^{*}$, Chao Dong \\ School of International Education Nanjing Institute of Technology I Hongjing Avenue 211167 Nanjing P.R.China \\ *Corresponding author. Email: 2649499989@qq.com
}

\begin{abstract}
In the development process of sino-foreign cooperative education, employment competence is an important standard to test the level of running a school and the sustainability of a project. The influence of the epidemic on the employment of college students has become a problem of increasing concern to colleges, society, and families. Sino-foreign cooperative education programs should not only meet the important task of introducing high-quality foreign educational resources and cultivating talents with international vision, but also start from the national conditions, expand employment channels, innovate training methods, and improve graduates' employment competence. Colleges and universities of sino-foreign cooperative education should strengthen the core ability of teachers, strengthen the cultivation of students' comprehensive quality, improve the social recognition, give full play to the advantages of cooperative education, and ensure the employment quality of graduates.
\end{abstract}

Keywords: Sino-foreign cooperative education, employment quality, graduates.

\section{INTRODUCTION}

In recent years, sino-foreign cooperative education has been supported strongly in Chinaby national policies. Since "Sino-foreign Cooperative Education Provisional Regulation" was issued in 1995, related institutions and programs have realized a "rapid growth". Relevant statistics show that in 1995 , there were only 71 programs nationwide. After over two decades of development, it has made outstanding progress. By the end of 2019, the institutions and programs had been set up by more than 600 colleges and universities in China, with a total number of 2,238, involving nearly 40 countries and regions, and more than 800 foreign colleges and universities. It includes more than 200 majors in 11 disciplines, such as science, engineering, agriculture, medicine, law, education, and so on. The institutions and programs recruit more than 150,000 students every year, with more than 600,000 students on campus, of which higher education accounts for more than $90 \%$ and there are more than two million graduates. At present, sinoforeign cooperative education has entered a new stage of high-level and demonstrating development. The education model is booming. Choosing such a novel education method can not only learn the advanced teaching mode and concept of foreign countries without going abroad but also greatly reduce the academic cost. However, compared with the domestic ordinary colleges and universities, whether the students of this education mode have obvious competitiveness in employment is a problem worth discussing. The difficult employment of college students under the epidemic situation has become an urgent problem to be solved. Due to the imbalance between the supply and demand of talents in the market, most enterprises are rather strict in selecting talents for college students. To save manpower and financial resources, many enterprises also set the requirement of working experience in recruitment.

On the contrary, graduates of sino-foreign cooperative education have certain talent advantages from the perspective of international talent cultivation. However, under the epidemic situation, reasons like the declining world economy, the narrowing path of studying abroad, the low recognition of domestic enterprises to this mode, and students' higher expectations in depth and goals of professional knowledge compared with ordinary students may restrict their employment. In the face of social tension and severe test, how to make these graduates of sino-foreign cooperative education colleges have more powerful employment competence will 
become a problem that we need to pay close attention to and need to solve urgently.

\section{REVIEW OF THEORIES AND PRACTICES ON ELEVATING EMPLOYMENT COMPETENCE OF SINO- FOREIGN COOPERATIVE EDUCATION}

Regulations of the People's Republic of China on Sino-Foreign Cooperative Education stipulates that sinoforeign cooperative education refers to the educational and teaching activities jointly held by Chinese educational institutions and foreign educational institutions within the territory of China with Chinese citizens as the main target of enrolment. Sino-foreign cooperative education refers to the cooperation between foreign legal person organizations, individuals and relevant international organizations and educational institutions, and other social organizations with Chinese legal person status to set up educational institutions with Chinese citizens as the main objects and carry out educational and teaching activities within the territory of China. After nearly 40 years of development, it has become an organic part of the whole education cause in China and is an important part of social undertakings in the process of opening to the outside world.

It is pointed out in the article "Analysis on reform and development policy of sino-foreign cooperative education" : The policy of sino-foreign cooperative education has experienced the process from very prudent to limited open and then to active prudent, and it has been developed to a certain extent. However, there are still many problems, such as differences in development orientation, inconsistent school-running directions, irregular school-running behaviours, unsmooth coordination between departments, the prominent contradiction between supply and demand, etc. In the era of information, the market demand for human resources is limited, while a large number of graduates flood into the market at the same time over a period of time. In addition, due to the transformation of China's industrial structure, the number of unemployed people has increased. At present, it blindly introduces international high-quality education resources and ideas, but lacks the integration and innovation of school-running ideas, teaching management, talent cultivation, and reshaping the education process and education ideas in combination with the development rules of Chinese higher education, thus establishing a student-centered education scene throughout the process. To sum up, sino-foreign cooperative education colleges and universities should combine high-quality teaching resources, excellent teaching facilities, and cooperate with the domestic education environment to achieve the combination of many aspects and diversified integration, so as to improve graduates' employment competence.

\section{ANALYSIS OF PROBLEMS IN EMPLOYMENT COMPETENCE OF SINO- FOREIGN COOPERATIVE EDUCATION}

\subsection{Lack of social recognition}

Based on the investigation of nine sino-foreign cooperative universities with independent legal entity, it is found that the social recognition of them is generally not high. Therefore, it is not difficult to find that although these colleges and universities have high-quality educational resources, they do not occupy an advantage among the majority of students and their parents, which will directly lead to two problems: Excellent students give up the choice of sino-foreign cooperative education colleges and universities due to lack of understanding and lack of trust; Enterprises, due to the lack of a correct understanding, reduce the opportunities given to sinoforeign cooperative education colleges and universities during its recruitment.

To improve the quality of running a school, sinoforeign cooperative universities with independent legal entity also hopes to select high-quality students in addition to providing high-quality international educational resources. All nine sino-foreign cooperative universities with independent legal entity institutions require candidates' scores to meet the first-batch admission line of their province, and some institutions will put forward requirements for the scores of foreign languages and single subjects. In order to recruit more suitable students, these institutions are also innovating in their recruitment models. There are mainly two ways of recruitment and selection, that is, the general recruitment and selection based on the results of the college entrance examination and the comprehensive evaluation recruitment and selection based on the results of the college entrance examination. Among them, Shanghai New York University, Kunshan Duke University, and Shenzhen MSU-BIT University fully adopt the comprehensive evaluation method of admission, through the "campus Open Day" and other activities, so that the school and students can have a comprehensive understanding of each other, and make a better "two-way choice". Although such a novel recruitment method is very attractive, it is prone to encounter many difficulties in its implementation. For example, some excellent students give up the preparation of documents, documents, and interviews to save time in preparing for the college entrance examination. This will lead to the loss of some of the best students.

At the same time, from the employment quality reports of these universities in recent years, we can find that most of the top 100 enterprises do not give an olive branch to some sino-foreign cooperative education universities. And these graduates from sino-foreign cooperative education colleges can only enter the uppermiddle level enterprises for the best, far lower than the 
expected top-level standard. In fact, the conservative behaviour of some of the top 100 companies can be traced back to the fact that sino-foreign cooperative universities are almost in their own league in China.

Regulations of the People's Republic of China on Sino-Foreign Cooperative Education clearly proposes that "The state encourages sino-foreign cooperative education institutions to introduce courses and textbooks that are urgently needed in China and advanced in the world." These schools use a completely different set of teaching materials and receive different education from ordinary college students in China. When enterprises are faced with two competitors from different education systems at the same time, they may not be able to objectively and clearly judge which one is better by parallel comparison of the overall performance of the candidates. In other words, they cannot judge which of the students trained in the two different modes are more suitable for employment in domestic companies. Nowadays, the competition among enterprises is also very fierce. In order to present a sound growth trend of enterprise scale and benefit, continue to deepen the structural adjustment, and highlight the international status of research and innovation, enterprises will be more conservative and tend to choose graduates from domestic ordinary universities rather than from a sinoforeign cooperative university. It can be known from the understanding that the tuition of these colleges and universities is generally high, and the learning environment is different from that of ordinary colleges and universities. Students' goals are often too high, even prone to the phenomenon of ambition, so in today's social environment is easy to fall into a vicious circle of "not high but not low", resulting in more difficult employment.

\subsection{Lack of ideological and political education}

Nowadays, ideological and political education in Chinese colleges and universities has a relatively mature scale and system. It not only provides ideological and political courses for students but also holds relevant lectures or activities from time to time in ordinary times. However, in these universities and colleges, we can find that the ideological and political education for students is extremely deficient. These students are living on Chinese soil and receiving foreign education, which is basically westernized from the system to the content. We also know that there are differences in some concepts and behaviors between China and foreign countries to some extent. Western countries advocate independence and freedom in academic construction and some social behaviors, while China is more inclined to system and norms. Accepting education that is different from the reality of our country, some immature students can easily go astray. However, most of these students who excessively advocate freedom and blindly believe in themselves are from well-off families and feel too good about themselves. Combined with the wrong interpretation of international diversified education, they have a shallow awareness of rules and even make some elementary mistakes when they cannot finish their studies as earnestly as other students. These will become fatal defects in employment. Such seemingly individualistic but unruly behaviour is not only not recognized in China, but also difficult to make a living abroad. Just like $\mathrm{Hu}$ Mingyan said: "A qualitative data analysis was conducted on 122 self-appraisal reports on transnational higher education programs submitted to China' s Ministry of Education in 2017 by 112 Chinese host universities. The analysis identified and examined relationships between four interrelated factors: low foreign language proficiency among students, shortage of a sustainable supply of highly qualified teachers, low quality of curriculum design and implementation and deficiencies in institutional regulations." At present, this mode pays too much attention to subject construction, emphasizes the depth of courses and the enhancement of education difficulty, and fails to realize the weakness of ideological and political education for students, which makes some students who should be more excellent fail to reach their due level.

\subsection{The teaching content lacks the integration with the social reality}

Through the collection of information on the official website, close access to classes, and interviews with students, we found that the professional centers of sinoforeign cooperative universities generally tend to focus on research fields and finance majors, which are different from the many majors available in domestic colleges and universities. This will directly lead to the training convergence of these graduates, which not only reduces employment competence with other ordinary college graduates but also increases the internal competition. Through understanding, we know that many students think that they want to continue to study when they graduate from the senior year because they think that the knowledge they have learned in the undergraduate stage is not incisive and comprehensive enough, and they are afraid of not having strong competitiveness in employment. Although these colleges and universities have internationally advanced education resources and provide high-quality education services, they are relatively limited in the choice of majors. At the same time, these colleges and universities blindly emphasize internationalization, pay no attention to the inheritance and development of major characteristics, and ignore the cultivation and improvement of students' comprehensive ability. As a result, students lack the ability of lifelong learning and adapting to social competition, and ultimately, are likely to lose their competitiveness in the employment market. Stephen Wilkins states in the 
research literature that "The need for a higher education qualifications framework and an effective system for assessing the quality and standards of British universities and their programs offered overseas are considered in the context of the United Kingdom achieving its government's market share targets for international feepaying higher education." Meanwhile, he thinks that “ It is argued that with increasing competition in the international higher education market, the United Kingdom government and United Kingdom universities must take greater care to consider overseas markets when making HE policy decisions if the export of British higher education is to be successfully increased." In foreign countries, most preparatory courses are provided to help students adapt to the transition in advance, while domestic students do not. As a result, students' knowledge basis is not solid enough, the study pressure is huge but the effect is not significant enough, and they focus on the completion of the graduation task but lack long-term consideration about the employment plan.

\section{ANALYSIS ON STRATEGIES TO ELEVATE EMPLOYMENT COMPETENCE OF SINO-FOREIGN COOPERATIVE EDUCATION}

\subsection{Actively strengthen publicity}

The sino-foreign cooperative education system has been established since the 1990s. After nearly 30 years of development, the scale and types in higher education have been further expanded, and it has played an important role in introducing foreign high-quality educational resources, improving the level of discipline construction, optimizing the mode of training international talents, and promoting the reform of education system. In particular, with the continuous improvement of the construction level of the "Double First-class Initiative", the pace of building such colleges and universities is constantly accelerating. It is also known as "studying abroad without going abroad". As a relatively low-cost way to receive international education, it has attracted more and more attention from students and parents.

In today's society, although strength is the absolute principle, positive publicity is also essential. In these nine sino-foreign cooperative universities with independent legal entity, we can also find that a few of the universities that actively promote, such as $\mathrm{Xi}$ 'an Jiaotong-Liverpool University and University of Nottingham Ningbo, have an increasing social recognition year by year, and the employment rate has also reached a record high. These two schools have been running for a long time and have good publicity means, which has increased their social visibility. The employment reports over the years have been released to the public, so many excellent students are willing to choose these two schools.
In addition, some other sino-foreign cooperative education universities, such as Shanghai New York University and Kunshan Duke University, have internationally advanced teaching equipment and education ideas and adopt liberal arts and general education programs. Their faculty teams are also made up of elites from East China Normal University and New York University, as well as Wuhan University and Duke University. However, because their propaganda efforts in the society are too insufficient, and the promotion of the city is not enough so that few people know and understand them. And many excellent students will naturally exclude them when choosing. At the same time, due to the poor publicity of these schools in the society, and lack of complete employment reports for several years, so enterprises are more inclined to choose a conservative attitude when facing the graduates of these schools, resulting in a sharp decline in employment competence of graduates of these schools.

Mary Hayden thinks that "One area in which the impact of globalisation can be seen is that of education. This article suggests that there are currently two main aspects of the growing internationalisation of education at school level: the internationalisation of national systems of education and the growth in numbers of international schools worldwide. It is the latter that forms the main focus of the article, beginning with consideration of the background to the development of international schools. A discussion of the changing nature of international schools then follows, as this form of education proves increasingly attractive not only to the globally mobile expatriates for whom such schools were originally founded, but also to those seeking a competitive edge for their child in a globalised market." The methods to improve employment competence are also very simple. The first is to increase the publicity in the society, and the second is to increase the publicity to the audience. Sino-foreign cooperative universities with independent legal entity are independent schools with broader departments. On the one hand, the characteristic majors are reflected according to the specialty construction of Chinese colleges and universities; on the other hand, basic subjects such as mathematics and chemistry are strengthened. Among the 9 colleges and universities, the disciplines offered most are: engineering, science, economics; The majors offered most are: mathematics and applied mathematics, economics, computer science and technology, biological sciences, and environmental sciences. After years of development, these colleges and universities have gone out of their own distinctive way of running schools. They publicize their own characteristics, distinguish them from ordinary colleges and universities in China, and form their own unique style to attract more outstanding students. Also, their foreign partner universities are all world-renowned universities. 
Except for Wenzhou-Kean University, the QS ranking of the other eight foreign partner universities is all within 300. Students can obtain better educational resources with fewer scores, which is also an attractive feature. These schools can publicize employment quality reports over the years, students' awards, school achievements, campus construction and academic construction on their official websites, so as to provide opportunities for excellent students to publicize and communicate with colleges and universities in various cities, or use various media platforms like Weibo and Douyin to publicize the school. They increase the publicity to the audience means to promote excellent high school graduates in various cities with a targeted purpose, recruit more excellent students and cultivate them, so as to improve employment competence of future graduates.

\subsection{Strengthen employment education in light of the characteristics of the Chinese market}

In China, only a certain sense of norms and abilities in all aspects except book knowledge can be considered as having a certain extent of social survival ability. Sometimes even if they have a strong ability to absorb knowledge or a profound knowledge reserve, but lack other abilities, they can only be called a crowd with "high score but low ability". However, in today's society, only having the ability to learn is far from enough. Enterprises pay more attention to students with all-round development, who have a sense of rules, understand interpersonal communication, master professional knowledge and reserve other interests. Such students are the talents that enterprises are really seeking for.

In order to combine with the Chinese market to strengthen all aspects of education, sino-foreign cooperative education colleges and universities can appropriately learn from Chinese ordinary colleges and universities, combined with the characteristics of foreign courses, carrying out courses around the ideological and political teaching materials and the characteristics of sino-foreign cooperative education. "The expansion of transnational higher education programmes over the last decade has foregrounded the themes of internationalisation, cross-cultural learning and cooperation in international research, whilst also raising questions about the appropriateness of educational programmes originally tailored for very different contexts, about the nature of the teaching and learning experience and regarding the assurance of standards and quality across geographically, culturally and educationally remote contexts. " In peacetime, the fragmented time is used to let students learn the Marxist world outlook and materialism, the theoretical connotation of the continuous development of the Communist Party of China, strengthen the comparative study of Chinese and Western politics and culture, and establish a strong national identity. The development of students' personality is the growth rule and learning characteristic of the youth in this new era. In the era of global communication with diverse values, students present different personality characteristics. In the process of knowledge transmission, the teaching content and carriers are enriched. The combination of online and offline as well as classroom and practice enables students to have a deeper insight into cultural confidence, national identity and rule observance, and strengthens students' abilities in all aspects, which focuses on more than mere expertise.

\subsection{Provide individualized education targeted for the employment direction of graduates}

In recent years, sino-foreign cooperative education colleges and universities emphasize the innovation of diversified education. Foreign curriculum is introduced to China, and knowledge is taught by both Chinese and foreign teachers.

Although such liberal arts programs and the idea of diversity and integration are very advanced and highquality, the actual practice often ignores the development of individual students. Every student will have a different choice when it comes to employment, but the homogenization of talents in these colleges and universities will result in students not making progress in the fields they want to grow in.

Employment rate is the most commonly used index to reflect the degree of employment of college students. It refers to the percentage of the number of employed students in the total number of graduates, that is, the proportion of graduates who actually participate in employment. Under the premise that the total number of graduates in a certain period is certain, the more employed students, the higher the employment rate will be. In recent years, the employment rate of these colleges and universities can be found to be above $96 \%$, but most of the students still choose to go abroad for further study. Now the epidemic impacts both at home and abroad, and many students who plan to study abroad for career development or seek employment abroad have their plans completely disrupted. Therefore, these colleges and universities need to carry out personalized education for the employment direction of graduates, give more professional suggestions, set up a career studio to often make future planning for students in need, and help students prepare for employment in a targeted way. Päivi J Tossavainen thinks that " Higher education internationalisation is defined through three areas: mobility, multi-culturalism, and networking. "In this paper, a conceptual model for institutionalising internationalisation strategies is suggested. The three integrated elements of the model are pedagogy, operative arrangements, and decision-making. ” 
Chart 1.An analysis of the Sino foreign cooperative educational projects and institutions in the construction of "double first class" Universities

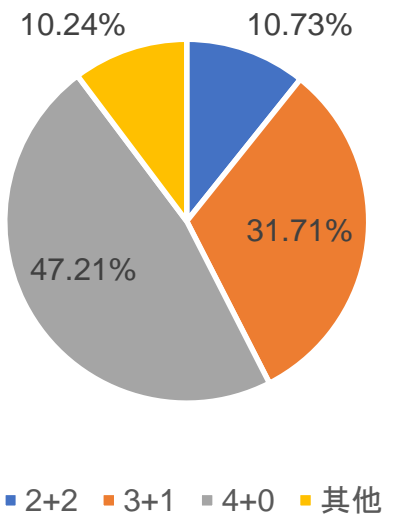

In Chart 1 , in all programs and agency systems in schools involved in "Double First-Class initiative" Sino-foreign cooperative education, those who plan to study abroad and those who have no plan to study abroad account for about the same proportion. It is known that these nine institutions all have a four-year length of schooling. Generally, there are three main ways, namely, $2+2,3+1$ or $4+0$. There are many opportunities for overseas exchange and study, and the educational system is more flexible. In addition, according to their own circumstances and academic performance, students can apply for exchange. Therefore, it is also an ingenious way to impart domestic and foreign educational resources through more convenient online distance learning. These schools can make reasonable use of the combination of online and offline methods, and use long-distance online education resources as the main teaching method. Foreign teachers can record class videos, transmit teaching documents online, or broadcast online, so as to make up for the gap that foreign teachers cannot teach in China and students cannot study abroad.

In addition, these schools should improve the comprehensive educational quality and ability of teachers, focus on student development, provide internship and practice programs, and strengthen employment skills. Through classified guidance, students with different needs can improve their core competitiveness around their respective learning purposes, so as to ensure that the advantages of graduates' employment competence are properly reflected.

\section{CONCLUSIONS}

Based on the investigation and research of nine Sino foreign cooperative colleges and universities, we can draw a conclusion that these colleges and universities have great room for improvement in social recognition, political and ideological education, and the correlation between teaching and the current situation of the job market. In the face of the global epidemic situation, the situation that people cannot go abroad to receive education makes people hesitant to choose these universities. In view of this situation, strengthening social propaganda, combining with the Chinese market to strengthen employment education and personalized education and training for graduates will play a particularly key role. The quality of employment is the most important aspect for people to judge the comprehensive quality of a school, and Sino foreign cooperation in running a school will attract the attention of the society because of its different school running mode and concept from ordinary universities. Therefore, to overcome many difficulties, actively deal with various defects, and effectively improve the employment competitiveness of Chinese foreign cooperatively run schools, the future of Chinese foreign cooperatively run schools is just around the corner.

\section{AUTHORS' CONTRIBUTIONS}

Runtong $\mathrm{Yu}$ and Chao Dong designed research, performed research, analyzed data, and wrote the paper.

\section{ACKNOWLEDGMENTS}

This research obtains the analysis of the path to improve the employment competitiveness of Sinoforeign cooperative education from the perspective of students -- based on the investigation project of nine independent legal entity Sino-foreign cooperative universities (No: 202011276136H)

\section{REFERENCES}

[1] T. Tian, Research on international talent training mode based on Sino foreign cooperation in running schools[J].International Public Relations, 2020 (10 ), pp. 227-228.

[2] Y. Tian,On the integration of "Curriculum Ideology and politics" into the English curriculum system of Sino foreign cooperative education[J].Science and technology vision, 2020 (30) . pp. 92-95.

[3] Wang. J, Improving the quality and efficiency of Sino foreign cooperative education with the reform of education evaluation[J].Research on Shanghai Education Evaluation, 2021, 10(01) pp. 38-43.

[4] Hu. M, higher education in China: a qualitative content analysis on Chinese host universities' selfappraisal reports. pp. 306-321 . Published online: 16 Mar 2019.

[5] Wilkins, Stephen . Student and employer perceptions british higher education in the Arabian Gulf region . 
pp. 157-174 . Published online: 16 Feb 2011. DOI: https://doi.org/10.1080/13596740100200104

[6] Hayden, Mary . Transnational spaces of education: the growth of the international school sector . pp. 211-224 . Received 05 May 2010, Accepted 16 Aug 2010, Published online: 24 Jun 2011. DOI: https://doi.org/10.1080/14767724.2011.577203

[7] Djerasimovic, Sanja . Examining the discourses of cross-cultural communication in transnational higher education: from imposition to transformation . pp. 204-216. Received 08 Nov 2013, Accepted 01 Mar 2014, Published online: 24 Apr 2014. DOI: https://doi.org/10.1080/02607476.2014.903022

[8] Tossavainen, Päivi J . Institutionalising internationalisation strategies in engineering education . pp. 527-543 . Received 26 Jun 2008, Published online: 31 Aug 2009. DOI: https://doi.org/10.1080/03043790903154457 